\title{
THE STRATEGIC IMPORTANCE OF THE SOUTH-EASTERN ASIAN SPACE REVEALED THROUGH SINO-AMERICAN POWER STRUGGLE
}

\author{
Ileana-Gentilia METEA \\ "Nicolae Bălcescu” Land Forces Academy, Sibiu, Romania \\ meteaileana@yahoo.de
}

\begin{abstract}
A development trend of the North Atlantic Alliance aims to the establishment of a "global NATO" as a political and military support of the West and of democratic states worldwide. The political-military and humanitarian cooperation in the former Yugoslavia, Iraq, Afghanistan, and Libya supports the materialization of such a structure. Some reservations are manifested because of the fears of some Western countries that they might be faced with a new global "Cold War" or engaged in armed conflicts in "sensitive areas" in the vicinity of the Russian Federation or China. That is why, maybe, the project of such a "new NATO" seems to be better received in Japan, Australia, and even the Gulf states. This paper aims to underline American vision, as the most important NATO member state, concerning the South-Eastern Asian space and also to put in discussion the Sino-American relations regarding this area.
\end{abstract}

Keywords: alliance, partnerships, global engagement, bipolarity, unipolarity

\section{Objectives of NATO Actions}

NATO's international commitment is based, first of all, on its partnerships. The central objective of extended partnerships is to maintain peace and stability in Europe and neighboring spaces [1]. In Afghanistan, NATO has resorted to military and civilian forces from Australia, Japan, South Korea and other partner countries. Today the region is marked by the issues of North Korea's nuclear arms. In addition, NATO is also involved in the Middle Eastern issue, a "global hydrocarbon reservoir". The United States, in their turn, initiated coalitions in the 1991 Gulf War and the 2003 Iraq intervention. For a while Washington and the allied capitals relied on the military-political restructuring of the region and countering Islamist regimes as well as fundamentalist Islamic organizations. In 2011-2013 an "Arab democracy" was "experienced", partially converted to Islamic fundamentalism. Eventually, it led to a big competition between the Sunnis and the Shia, specifically between Turkey, Egypt, Saudi Arabia and Iran (with its epicenter in Syria). In this context, the political and military offensive of Islamic parties and groups throughout North Africa and the Near and Middle East should also be emphasized [2].

\section{NATO - Global Commitment}

We recall that in 2011, a NATO intervention in Libya was completed. There is an international stabilization force between Lebanon and Israel. This latter state is a NATO partner and key ally of The United States. The US and allied forces take part in the fights against Islamists in Yemen and provide military protection to Saudi Arabia and the Gulf States. An American air and maritime 
force stationed in the region (two strategic and operative groups). The Americans proposed a "humanitarian military action" in Syria, as well, through NATO, with the approval of the UN Security Council. Beijing and Moscow's opposition annihilated that strategy. The Gulf States and Turkey, however, grant support to "Syrian rebels", mostly fundamentalists of the Sunni Muslim Brotherhood. RussianAmerican agreements in Geneva, in the fall of 2013, announce a political solution for Syria, as well [3]. NATO was involved directly and indirectly in other areas in Africa, as well. The Alliance has a distinct partnership with the UN. In the summer of 2005, NATO was asked to support other peace solutions, for example in Sudan. Starting from June 2005, for the first time, NATO as an institution conducted operations on African territory. The government in Khartoum used the Muslim population in the West as a base to recruit soldiers to fight for the extermination of the Christian population in the south. In June 2005, NATO has provided air transportation for 31.000 AMIS troops. Air support means strategic transportation (bringing troops from African countries donating troops close to the AMIS theater of operations), tactical transportation (within the theater of operations) and funding commercial transportation. All air operations were coordinated through the cooperation between the Joint Center for Management and Administration of Addis Ababa, the NATO Allied Movement Coordination Center under SHAPE and the European Centre for Air Transport in Eindhoven (operating under the EU, For the first time in the operations in Darfur, the EU did not use NATO capabilities in accordance with the Berlin Plus agreement). The African Union understood the importance of the assistance that NATO can provide and requested the help of the Alliance in supporting the mission in Somalia. At the same time, NATO has agreed to support the African Standby
Force (the ASF). Thus a contact was established with the AU with the purpose of creating the ASF ( The ASF is a continental force, which is intended to be used in Africa in times of crisis, as part of the AU efforts to increase capabilities and contribute to the broadening of international efforts for peace and security) . Beginning with June 2007, NATO decided to support the AU mission in Somalia (AMISOM) more seriously. Air support was provided for AU Member States that had committed to sending troops to Somalia under AMISOM. The escorting of a ship carrying US military equipment was guaranteed from Burundi for one of the battalions that NATO had carried by air to Mogadishu. NATO provides two experts for the Management and Strategic Planning unit belonging to the AU in the field of air coordination and human resource management [4]. Another initiative on the African continent began in October 2008 when the North Atlantic Council approved posting Member States' ships in the Horn of Africa region in order to escort ships of the World Food Program off the coast of Somalia and protect them against pirates. Indirectly, NATO and the US supported peace operations in Mali, Congo, and South Sudan etc.

\section{Tensions Accumulation in the Eastern and Southeastern Asian Space}

A Global NATO will not be able to bypass either the issue of the political and military rise of China in Asia or the role of the alliance between Beijing and and Moscow. While China is increasing its economic presence and strengthening its political relations with ASEAN, President $\mathrm{Xi}$ Jinping's tour in Indonesia and Malaysia in October 2013 being a symbol thereof, its relations with some members of the organization have deteriorated because of its inability to negotiate a solution to territorial disputes. These tensions have a lot to do with the 
strengthening of the diplomatic and military presence of the US in the AsianPacific region, as well as with Japan's investment strategy in Southeast Asia. Although the two great powers that the U.S. and China are, do not have a confrontation like the one between Moscow and Washington during the Cold War, Asia-Pacific and especially Southeast Asia represent a competition space between their influences. Each power seeks to befriend key partners among ASEAN Member States in order to increase their influence, making Southeast Asia a land of Sino-American competition.

Each of the medium and secondary powers in ASEAN has a unique opportunity to maximize their national interests in this competition by playing this game skillfully. ASEAN's official slogan of 2012 "One community, one destiny" appears as a facade behind which significant differences between Member States' strategies hide. Some experts consider that a bipolar system is about to appear in the region but the international system remains unipolar contrary to the will of a part of the academic world and the media, which promotes a so-called G2 (United States - China). The unipolar moment, which started according to Charles Krauthammer in 1991, is maintained despite the unprecedented emergence of China. The US president announced, without taking risks, in his speech on the state of the nation in 2011 that "no rival superpower is against us" [5], whereas the former Secretary of State Hilary Clinton announced before her departure from the Obama administration in early 2013 that "our military power, the size of our economy, the influence of our diplomacy and the creative energy of our people remain without rival" [6]. However, this does not mean that the US is a global hegemon able to impose its will in the face of all the other states of the international system. Regional subsystems are not entirely a reproduction of the international system. As stressed by Barry Buzan, certain regional subsystems are "subsystems with strong enough international features to be studied in themselves". We estimate that the South Eastern Asian system is characterized today by a bipolarity that is born between the US, which remain the main power of this subsystem, and China - a competitor which makes increasingly more to the fore.

From this observation several consequences derive. Firstly, no Southeast Asian state is able to compete with the USA or China. No state in the region is a great power. ASEAN members states are either medium or secondary powers. By superpower it is understood a state with global preeminence in all sectors: economic, military, diplomatic, ideological, technological and cultural. The US is a superpower. By great power it is understood a state with solid capacities and having a global influence. China is a superpower. By medium power or regional power it is understood a state whose capacities are important regionally but too limited to enable it to protect itself globally. Indonesia and Malaysia are medium powers. The other states are secondary powers with limited capacities, in particular projection ones. Laos or Cambodia are secondary powers. Southeast Asia thus becomes the land of competition between the two great powers of the international system that exceed regional rivalries between the states of the region. As with Western Europe since the $1950 \mathrm{~s}$, this bipolarity strengthens the possibilities for cooperation between the regions and allows a stronger institutionalization of the ASEAN. This bipolarity mitigates the tensions between ASEAN Member States as the main threat that they perceive is the one coming from the two great powers, and not from another Member State. Secondly, one can not speak of a "Cold War" between the US and China. The current configuration is 
indeed very different from the post-World War II one. The US and the Soviet Union had not reached a certain parity in the military field and Moscow was the main threat to US national security. At the same time, the Soviet Union was a "poor power", with limited trading with the Western bloc and almost nonexistent economic interdependence with the United States. The new China-US configuration is totally different. Despite the literature on the "Chinese threat", China does not represent today a military threat at the same level of that of the former USSR. China is not leading a military bloc, as it does not have a military alliance, if we don't consider the assistance treaty with North Korea signed in 1961. China has no military base outside its national territory. If the cyber-defensive capabilities are subject to special attention of Western powers, and the People's Liberation Army (PLA) is in the process of rapid modernization, this will only make up for the delay of decades in relation with the American and the Japanese forces. The first aircraft carrier (or more precisely the first modernization of a Soviet aircraft carrier) is not yet fully operational. The military projection capabilities remain limited. American military power exceeds by far Chinese military power in terms of quantity (the US military budget is four times higher than the Chinese) and in terms of quality. In Southeast Asia, these two great powers do not reproduce the US-Soviet Cold War scheme, marked by a confrontation between blocks, but create a new one. The US is and will remain for decades, the region's main military power through its power projection capabilities, but also by means of its regional military alliances (Japan, South Korea, Philippines, Thailand, and Australia). China is and will strengthen its position as the leading economic power, not only by the importance of its national economy, but also by the trade relations in the region, strengthened by the free trade agreement entered into force in 2010. China - even excluding Hong Kong in the statistics - is now the main trading partner of ASEAN, their bilateral trade exceeding $\$ 300$ billion in 2012 compared to $\$ 56$ billion in 2002. Chinese government's ambitions, as presented by $\mathrm{Xi}$ during his visit to Indonesia in 2013, are to overcome the symbolic barrier of 1,000 billion in 2020 .

We are witnessing the formation of a double hierarchy in Southeast Asia, every great power seeking to provide guarantees / benefits (security ones - US, economic ones - China) to the countries in the region. The United States has been for decades "the critical variable in the East Asian equation" (Nye, 1995), ensuring its partners and allies against China. China offers the promises of economic development. Examples of this economic leverage are posed by the proposal that the Chinese President made during his tour of South-Eastern Asia in October 2013, to create a development bank dedicated to infrastructures, or a swap agreement with Indonesia to exchange currencies in the order of 100 billion Yuan. In China there are voices that advocate a more offensive use of this economic leverage; the nationalist daily "Global Times" estimated that "any attempt to counter China by resorting to US diplomacy and their military power will have an economic price". This configuration presents major opportunities for Southeast Asian countries. These medium or secondary powers are able to stand up to the great powers. In their interactions and choice of alliances, they must choose between their imposing neighbors because, as pointed out by former Secretary of State Kurt Campbell, "the traditional balance of power calculations still animate interstate relations in East Asia" [7]. For most realistic academic specialist, these medium powers will ally with the weakest or the least threatening of the great powers in order to balance the regional system (balancing behavior). Randall Schweller, a 
realist, estimates that alliances are motivated "by earning opportunities, as well as by danger, desire as well as by fear", according to their degree of satisfaction through the international / regional system level and the opportunity to align with a dominant power (alignment behavior). Medium and secondary powers in Southeast Asia have the opportunity to not fall into one of these two scenarios. These countries can play a role in the Sino-American competition, receiving security guarantees from the US (balance) and economic benefits from China (alignment).

We estimate that each state's strategy in Southeast Asia depends symmetrically on several factors including their security relations with China (territorial disputes or not) and their regional power. States which benefit the most from the Sino-American competition are ASEAN secondary powers because ASEAN's functioning by consensus gives them the ability to block decisions by exercising their right of veto. Indeed, China and the US seek to gain an "indirect veto right" within ASEAN, offering their support and faith to these secondary powers. The meeting point of strategic issues in Southeast Asia is today the increasing tension in the South China Sea. These tensions reflect the growing opposition between China and the US, the divergences in their regional strategies, but also the differences between Member States and ASEAN. The South China Sea can be taken as a starting point in designating this regional subsystem's lines. Southeast Asia is, strategically, a transit zone between Europe, Middle East and East Asia, two of the three global economic poles. From China's point of view, the region, especially South China Sea, can serve as a strategic buffer zone to protect the coast, the economic center of the country. Names such as "the Asian Mediterranean" or "the Chinese Caribbean Sea" can often be found (In the US, or
France, in the works of Denis Lombard or François Gipouloux.) in order to qualify this maritime stretch of $3.5 \mathrm{~km}^{2}$. Some strategists believe that "Rome and the US have held control of the Mediterranean and Caribbean, China now seeks to dominate (South China Sea)" (Kotani, 2011).

Tensions between China and some countries like the Philippines and Vietna [8] are not exclusively due to the so-called emergence of China. Expert Carnegie Michael Swaine (2011), states that Chinese emergence is "the only dominant term in Sino-American relations in recent years", and the renowned professor David Shambaugh estimates that "2008-2009 will be remembered as the years in which China became difficult for the world to deal with". Real grievances and tensions of certain countries in the region in dealings with China are not new in themselves, but their public expression is. Territorial disputes between China and four ASEAN members (Vietnam, Philippines, Malaysia and Brunei) do not date back to 2008. However, several factors have led to an exacerbation of tensions regarding these disputes. One of these factors is the inexorable rise of China and the country's military modernization. China is becoming a maritime power, after a long time where it only had the capacity to be a continental power. Moreover, the fact that the imbalance between China and its neighbors in Southeast Asia increases has always been a reality. In addition, if China is more confident in its capacity, as retired General $\mathrm{Xu}$ Guangyu highlighted, its territorial claims in the South China Sea have not increased and China continues to comply with the strongly criticized "nine dash line". Peking avoids any internationalization of these territorial conflicts and treats them on a bilateral basis, thus avoiding American mediation. The official position is repeated almost daily by the Chinese Foreign Ministry as 
follows: "The core issue of the South China Sea sovereignty disputes (...) will be dealt with by direct negotiations between the relevant parties involved. (...) China has always maintained that disputes and differences over the South China Sea should be resolved properly through bilateral negotiations and friendly consultations between relevant countries". This Chinese strategy contradicts the American strategy summed up by Hillary Clinton in one sentence: "We remind the entire region of the irreplaceable role that America plays".

\section{Conclusions}

Sino-American tensions in the South China Sea will persist because of the ambiguity of the US asking China to respect the Montego Bay Convention (UNCLOS 1992), without having it ratified, and differences in its interpretation, in particular as regards the Exclusive Economic Zones (EEZ) and the possibility to conduct military exercises there. For China, which has ratified the Convention, a state can not carry out military operations, and therefore espionage, in the territorial waters of another State, including belonging EEZ. For the US, which has not ratified the Convention but refers to it, freedom of navigation in international waters, including EEZ is a basic principle of the Law of the Sea. China understands therefore, to make its EEZ, including the EEZ claimed in the South China Sea, buffer zones, free from all US military presence. These differences in interpretation are crucial, because there have been numerous military incidents and the risk of escalation is always present. We recall that Washington encourages a coalition of Japan, South Korea and India in order to balance Chinese power. In addition, the US has clear military alliances with Japan, South Korea, Australia, New Zealand, Philippines, Thailand, Taiwan and even Vietnam (unofficial).

\section{References}

[1]. The Collective Security Treaty Organization in www.geopolitics.ro ; R. Chiriţă, The US National Security Strategy, 2013

[2]. I.S. Ţuţuianu, The sunset of Westphalia, the Military Publishing House, Bucharest, 2011, p. $289 \mathrm{ff}$.

[3]. www.mfa.gov.sg/content Oct. 31, 2013, 5.00 PM

[4]. Deni, John R. The NATO Rapid Deployment Corps: Alliance Doctrine and Force Structure. Contemporary Security Policy 25:498-523 December 2004. http://taylorandfrancis.metapress.com/openurl.asp?genre=article\&id=doi:10.1080/1352326042000330628

[5]. B. Obama, State of Union Speech, Washington, 25.01. 2011

[6]. H. Clinton, On Leadership, CFR, Washington, January 2013

[7]. Kurt. M. Campbell, Regional Overview of East Asia and the Pacific, Statement Before the House Committee on Foreign Affairs Subcommittee on Asia, the Pacific, and the Global Environment, Washington DC, 30.03.2010.

[8]. www.fmprc.gov.cn/eng/zxxx/t1088644,html

[9].www.un.org/depts/los/conventuion_agreements/texts/unclos/closindx.htm 